\title{
Reserach Aвтіст: Evaluation of tractor drawn seed drill for sesame
}

Article Chronicle :

Received :

19.07.2017;

Accepted :

03.08.2017

\section{KeY WoRDS :}

Drilling, Seed drill, Field efficiency, Field capacity
Author for correspondence :

KALPANA DUDA

Regional Agricultural

Research Station

(PJTSAU), Polasa,

JAGTIAL (TELANGANA)

INDIA

Email : kalpana.duda@

gmail.com

See end of the article for authors' affiliations

\section{KALPANA DUDA AND G. PRAGNA}

SUMMARY : The study was conducted to assess the performance of tractor operated seed drill for sowing sesame seeds. The field tests were conducted on red sandy loam soil. The seed rate of the seed drill was less compared to traditional method of sowing. The seed rate obtained was $1.8 \mathrm{~kg} / \mathrm{ha}$. The field capacity and effective field efficiency was found to be $0.35 \mathrm{ha} / \mathrm{h}$ and $63 \%$, respectively. The fuel consumption was found to be $4 \mathrm{lph}$ with the work rate of $2.87 \mathrm{~h} / \mathrm{ha}$. The cost of sowing was less with the planter when compared to traditional methods of sowing. Seed, time and labour can be saved with the seed drill compared to manual methods of sowing. The technology assessed better performance over farmers practice. Due to more fatigue, it was suggested that power operated equipment was better than traditional method for sowing.

How to cite this article : Duda, Kalpana and Pragna, G. (2017). Evaluation of tractor drawn seed drill for sesame. Agric. Update, 12(TECHSEAR-7) : 1833-1837; DOI: 10.15740/HAS/AU/12.TECHSEAR(7)2017/1833-1837. 